\title{
EDUKASI PERILAKU HIDUP SEHAT PADA LINGKUNGAN SEKOLAH
}

\author{
Wati Asriningsih Pranoto ${ }^{1}$, Gregorius Sandjaja $S^{2}$, Inda Sumarli ${ }^{3}$, dan Alfred J. Susilo ${ }^{4}$
}

\author{
${ }^{1}$ Program Studi Magister Teknik Sipil, Universitas Tarumanagara Jakarta \\ Email: watip@ft.untar.ac.id \\ ${ }^{2}$ Program Studi Sarjana Teknik Sipil, Universitas Tarumanagara Jakarta \\ Email: gregoriuss@ft.untar.ac.id \\ ${ }^{3}$ Program Studi Sarjana Teknik Sipil, Universitas Tarumanagara Jakarta \\ Email: indas@ft.untar.ac.id \\ ${ }^{4}$ Program Studi Sarjana Teknik Sipil, Universitas Tarumanagara Jakarta \\ Email: alfred@ft.untar.ac.id
}

\begin{abstract}
The situation and conditions with the COVID-19 pandemic have made students to Learn From Home (BDR). This situation has been going on for more than 1 year since March 2020, the government, in this case, the Ministry of Education and Culture has given directions to open Face-to-face Learning (PTM) in the even semester of 2020. From the studies conducted, many schools (>80\%) in Indonesia are ready for PTM. The directives from the government have been stated in the Joint Decree (SKB 4 ministers dated June 15, 2020 and revised on August 7, 2020 and March 30, 2021. The school authorities must improve the schools to prepare for the opening of this PTM after a long BDR, especially SMAN 96 West Jakarta which is a partner in this Community Service. Preparations must be made in accordance with the government's directive in the SKB. How are students preparing to do PTM? What should be done? To help the schools keep the PTM running well and safely, it is necessary to make education about healthy living behaviors for students in the school environment. This education includes :1. Education on preparation for school (while still at home),2. Education when students arrive in the school area, 3. Education during learning activities,4. Education on leaving the classroom when the lesson is finished, 5.Education when arriving at home after school and start doing activities at home. The results of this community service are in the form of pocket books and behavioral education presentation materials on how to live a healthy life in the school environment for students.
\end{abstract}

Keywords: behavior, students, healthy living, environment

Situasi dan kondisi dengan adanya pandemi covid 19 membuat pelajar atau siswa sekolah Belajar Dari Rumah (BDR). Keadaan ini sudah berlangsung lebih dari 1 tahun sejak Maret 2020, pemerintah dalam hal ini kemdikbud sudah memberi pengarahan untuk membuka Pembelajaran Tatap Muka (PTM) pada semester genap 2020. Dari penelitian-penelitian yang dilakukan, banyak sekolah $(>80 \%)$ di Indonesia siap untuk PTM. Arahan dari pemerintah sudah tertuang dalam Surat Keputusan Bersama (SKB 4 menteri pada tertanggal 15 Juni 2020 dan revisi pada tanggal 7 Agustus 2020 serta 30 Maret 2021. Pihak sekolah harus berbenah untuk mempersiapkan sekolah dalam pembukaan PTM ini setelah sekian lama BDR, khususnya SMAN 96 Jakarta Barat yang menjadi mitra dalam Pengabdian pada Masyarakat ini. Persiapan yang dilakukan harus sesuai dengan arahan pemerintah dalam SKB tersebut. Bagaimana persiapan siswa dalam menghadapai PTM? Apa yang harus dilakukan? Untuk membantu pihak sekolah agar PTM berjalan baik dan lancar serta aman, maka perlu dibuat edukasi perilaku hidup sehat bagi siswa dalam lingkungan sekolah. Adapun edukasi ini melingkupi:1. Edukasi persiapan ke sekolah (saat masih di rumah), 2. Edukasi saat siswa melangkah masuk pekarangan sekolah, 3. Edukasi selama kegiatan belajar, 4. Edukasi saat pembelajaran selesai dan keluar ruang kelas lalu pulang, 5. Edukasi saat sampai di rumah dan mulai berkegiatan di rumah. Hasil dari pengabdian pada masyarakat berupa buku saku dan materi presentasi edukasi perilaku hidup sehat bagi siswa di lingkungan sekolah.

Kata kunci: perilaku, siswa sekolah, hidup sehat, lingkungan

\section{PENDAHULUAN}

Hasil survei dari UNICEF awal Juni 2020 adalah 66 persen peserta didik merasa bosan/jenuh belajar dari rumah/BDR dengan 4.016 responden di 34 provinsi. Sedangkan hasil penelitian dari Komisi Perlindungan Anak Indonesia (KPAI) dengan survei Pembelajaran Jarak Jauh (PJJ), 13- 
20 April 2020: 76,7 \% siswa merasa tidak senang belajar dari rumah; kesulitan mengerjakan berbagai tugas. Survei dilakukan pada 1.700 siswa SD - SMA/SMK di 20 provinsi dan 54 kabupaten/kota di Indonesia.

Survei lain sekaligus penelitian dilakukan dengan total 48 Responden pada 21Nov s.d. 6 Des.2020 (46 Kepala Sekolah, 2 Wakasek) di Disdik; DKI, Jabar, NTT, Kota Yogya, Kota Kupang, Kab. Serdang Bedagai, Kab. Polman, Kab. Aceh Besar, Kab.50 Kota. Penelitian dilaksanakan dengan wawancara online/Telp./Whatsapp, Forum FGD, data sekunder. Hasil penelitian yang diperoleh:

81,3\% Sekolah Siap \& Mendukung,

$10,4 \%$ Peninjauan Kembali

8,3\% Belum Siap Tatap Muka, Menunggu Arahan Disdik/Pemkab/ Pemkot/Gubernur/ Kanwil Kemenag, Satgas, Ortu/Komite

Kebijakan Pembelajaran Tatap Muka (PTM) - Surat Keputusan Bersama (SKB) 4 Menteri Pendidikan dan Kebudayaan, Menteri Agama, Menteri Kesehatan, Menteri Dalam Negeri :

- SKB 4 Menteri 15 Juni 2020: izin pembukaan pembelajaran tatap muka terbatas wilayah zona hijau,

- SKB 4 Menteri revisi 7 Agustus 2020: Relaksasi pembukaan pembelajaran tatap muka wilayah zona kuning

Pemerintah mulai menyampaikan persiapan pembelajaran luring untuk tahun 2021 pada 15 Desember 2020. Pemerintah dalam hal ini Mendikbud membolehkan Pembelajaran Tatap Muka (PTM) di awal semester genap, Januari 2021 dengan beberapa ketentuan (Kemko PMK, dan Kepala BNPB/Ketua Gugus Tugas Penanganan Covid-19). Fokus pada pelaksanaan pendidikan dari PAUD, SD, SMP, SMA sederajat dan SLB, selain protokol kesehatan sehari-hari.

Berdasarkan penelitian yang telah dilakukan Nugroho dkk (2020), kesiapan kegiatan PTM di Indonesia pada tahun 2021 bahwa pemerintah dan masyarakat harus menyiapkan sumber daya manusia, sarana dan prasarana, mengurus perizinan, serta melaksanakan imunisasi vaksin COVID-19

Kebijakan PTM dikeluarkan kembali dengan terbitnya SKB 4 Menteri 30 Maret 2021 tentang Panduan untuk Penyelenggaraan Pembelajaran di Masa Pandemi Corona Virus Disease 2019 (COVID-19. Penyelenggaraan pembelajaran di masa pandemi Corona Virus Disease 2019 (COVID-19) dilakukan dengan:

a. pembelajaran tatap muka terbatas dengan tetap menerapkan protokol kesehatan; dan/atau b. pembelajaran jarak jauh.

Mengikuti perkembangan pandemi covid yang dimulai sejak awal Maret 2020 di Indonesia, meningkat, menurun dan terakhir bulan Juni 2021 meningkat drastis dengan tersebarnya virus varian baru (alpha, beta, dan delta). Berdasarkan penghitungan Kompas.com, 2 juta kasus Covid-19 pada 21 Juni 2021 menuju 3 juta kasus pada 22 Juli 2021 membutuhkan waktu sekitar 32 hari. Selanjutnya penyebaran virus varian baru di atas butuh waktu sekitar 34 hari dari 3 juta kasus pada 22 Juli 2021 hingga mencapai 4 juta kasus pada 24 Agustus 2021 (Sahara, 2021). Perkembangan yang terjadi membuat masyarakat harus tetap menjaga protokol kesehatan yang sudah dicanangkan sejak mulai merebaknya pandemi covid ini. Dari protokol kesehatan 3M menjadi 5M. Bagaimana pelaksanaan pendidikan yang baik agar siswa tetap mendapat pendidikan terbaik dalam masa pandemi ini? Persiapan Pembelajaran Tatap Muka bukan hanya dilakukan pihak sekolah tetapi juga siswa beserta orang tuanya.

Sekolah yang menjadi mitra dalam Pengabdian pada Masyarakat ini adalan SMAN 96 yang berlokasi di Jl. Jati Raya No.40, RW.12, Kapuk, Kecamatan Cengkareng, Kota Jakarta Barat, Daerah Khusus Ibukota Jakarta 11730.

Pihak sekolah dalam hal ini, SMAN 96 harus membuat persiapan dalam rangka PTM dengan mengikuti kebijakan SKM 4 menteri yang sudah disebutkan di atas. 
Pihak SMAN 96 harus mempersiapkan protokol kesehatan dalam PTM sekolah 2021, yaitu:

1. Kondisi kelas

- Jaga jarak: minimal 1,5 meter,

- Jumlah maksimal peserta didik per kelas,

SMA sederajat: 18 (dari standar 36 peserta didik),

2. Jadwal pembelajaran

Sistem bergiliran rombongan belajar (shifting): ditentukan oleh masing-masing satuan pendidikan.

3. Perilaku wajib

- Menggunakan masker kain 3 (tiga) lapis/masker sekali pakai/masker bedah,

- Cuci tangan pakai sabun dengan air mengalir atau menggunakan hand sanitizer,

- Menjaga jarak minimal 1,5 meter dan tidak melakukan kontak fisik

- Menerapkan etika batuk/bersin,

4. Kondisi medis warga satuan pendidikan

- Sehat dan jika mengidap comorbid harus dalam kondisi terkontrol

- Tidak memiliki gejala COVID-19 termasuk pada orang yang serumah dengan warga sekolah.

5. Kantin:

- Masa transisi: tidak diperbolehkan;

- Masa kebiasaan baru: diperbolehkan dengan protokol kesehatan.

6. Kegiatan olahraga dan ekstrakurikuler

- Masa transisi: tidak diperbolehkan

- Masa kebiasaan baru: diperbolehkan kecuali kegiatan yang menggunakan peralatan bersama dan tidak memungkinkan penerapan jaga jarak minimal 1,5 meter, misalnya basket dan voli.

7. Kegiatan selain pembelajaran

- Masa transisi: tidak diperbolehkan ada kegiatan selain Kegiatan Belajar Mengajar (KBM).

Contoh yang tidak diperbolehkan orang tua menunggu siswa di sekolah, istirahat di luar kelas, pertemuan orang tua-murid, dsb

- Masa kebiasaan baru: diperbolehkan dengan protokol kesehatan

8. Pembelajaran di luar lingkungan satuan pendidikan: diperbolehkan dengan protokol kesehatan.

Dari pihak SMAN 96 harus menyiapkan prokes di atas, lalu bagaimana dengan pihak siswa selain perilaku wajib di atas, apa yang harus dipersiapkan? Menjawab pertanyaan ini, siswa harus dibekali dengan edukasi etika perilku hidup sehat dalam lingkungan sekolah sehingga siswa menjadi terbiasa berperilaku hidup sehat, bukan hanya di lingkungan sekolah tetapi juga saat di luar rumah.

Sekolah, khususnya SMAN 96, menghadapi PTM setelah lama BDR (Belajar dari rumah), maka perlu waktu, tenaga, keuangan dalam mempersiapkan prokes yang diminta selain semua tenaga pendidik sudah harus mendapat vaksinasi. Siswa diminta dengan 4 perilaku wajib. Masih banyak yang harus diedukasi bagi siswa dalam tatanan hidup baru yang harus berdampingan dengan covid 19. Pengabdian pada masyarakat perlu dilakukan untuk memberi edukasi perilaku hidup sehat pada siswa saat di lingkungan sekolah khususnya dan persiapan dari rumah serta saat sampai di rumah. Bentuk pengabdian pada masyarakat berupa buku saku untuk dibagikan saat memberi presentasi untuk memberi edukasi perilaku hidup sehat di sekolah.

Berikut foto foto situasi dan kondisi SMAN 96 sebagai berikut:

Gambar 1 merupakan gambar gerbang sekolah SMAN 96 Jakarta 
Gambar 2 adalah gambar halaman depan sekolah merupakan gambar situasi setelah masuk gerbang sekolah, jalan ke arah kanan adalah menuju parkiran motor dan mobil. Jalan ke arah kiri adalah jalan masuk ke dalam sekolah.

Gambar 3 adalah wastafel di halaman sekolah

Gambar 4 adalah wastafel kantin sekolah

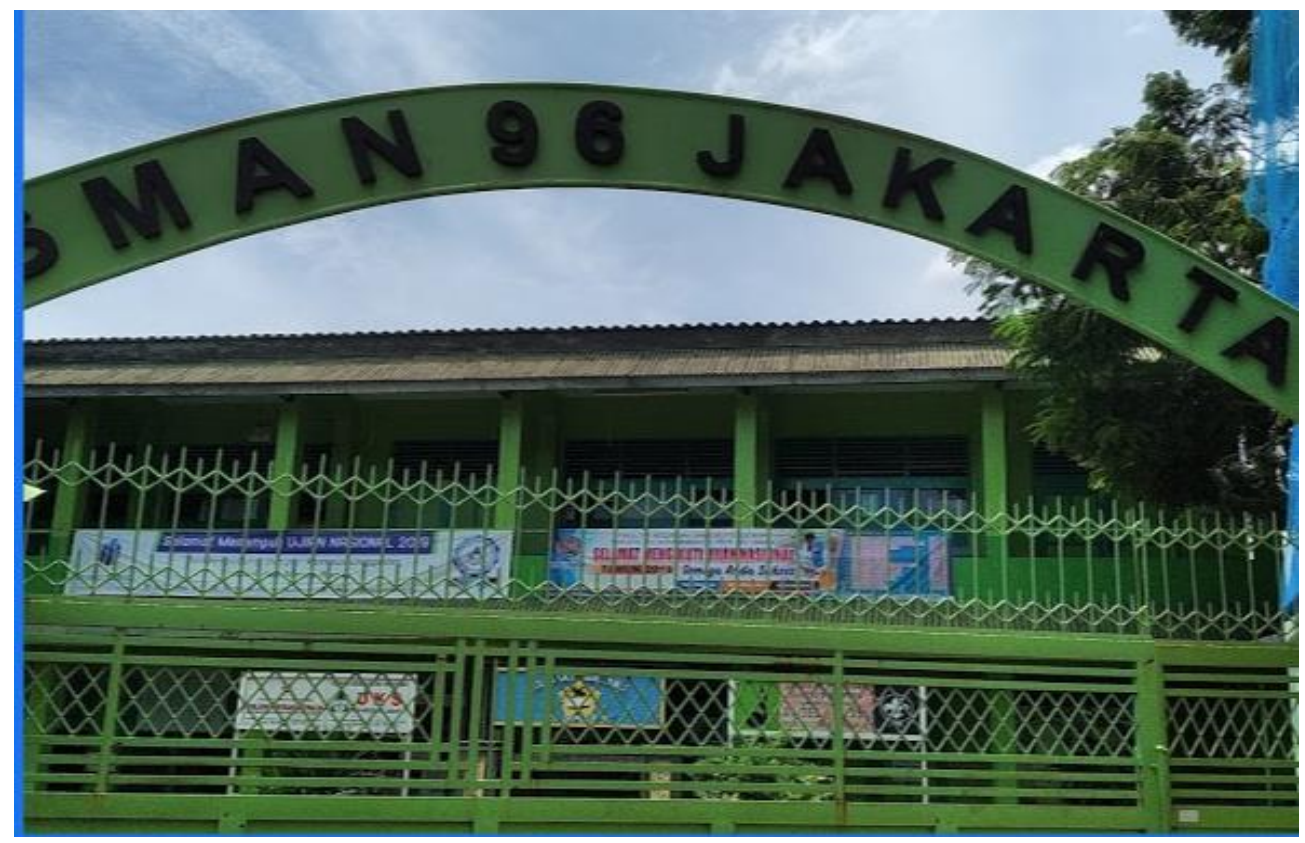

Gambar 1. Gerbang sekolah SMAN 96

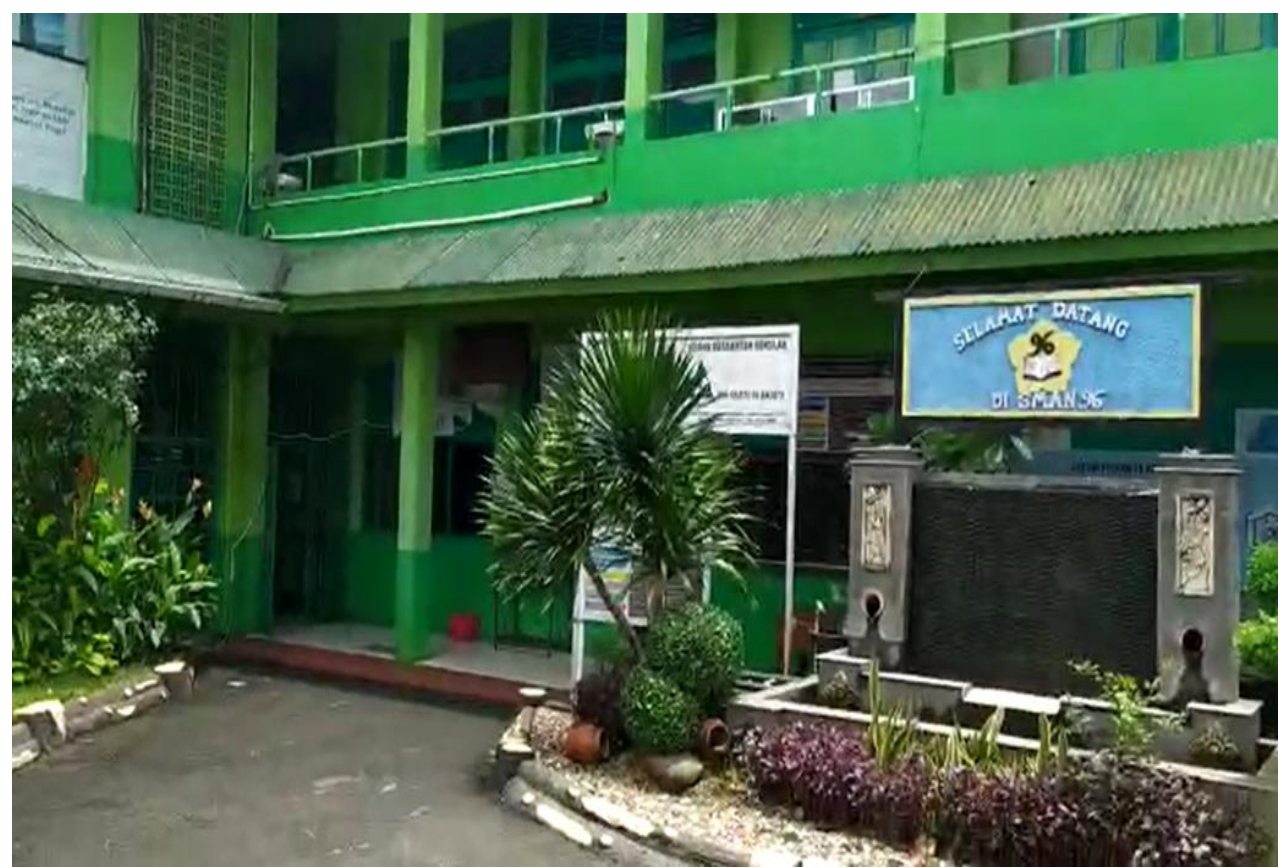

Gambar 2. Halaman di Sekolah 


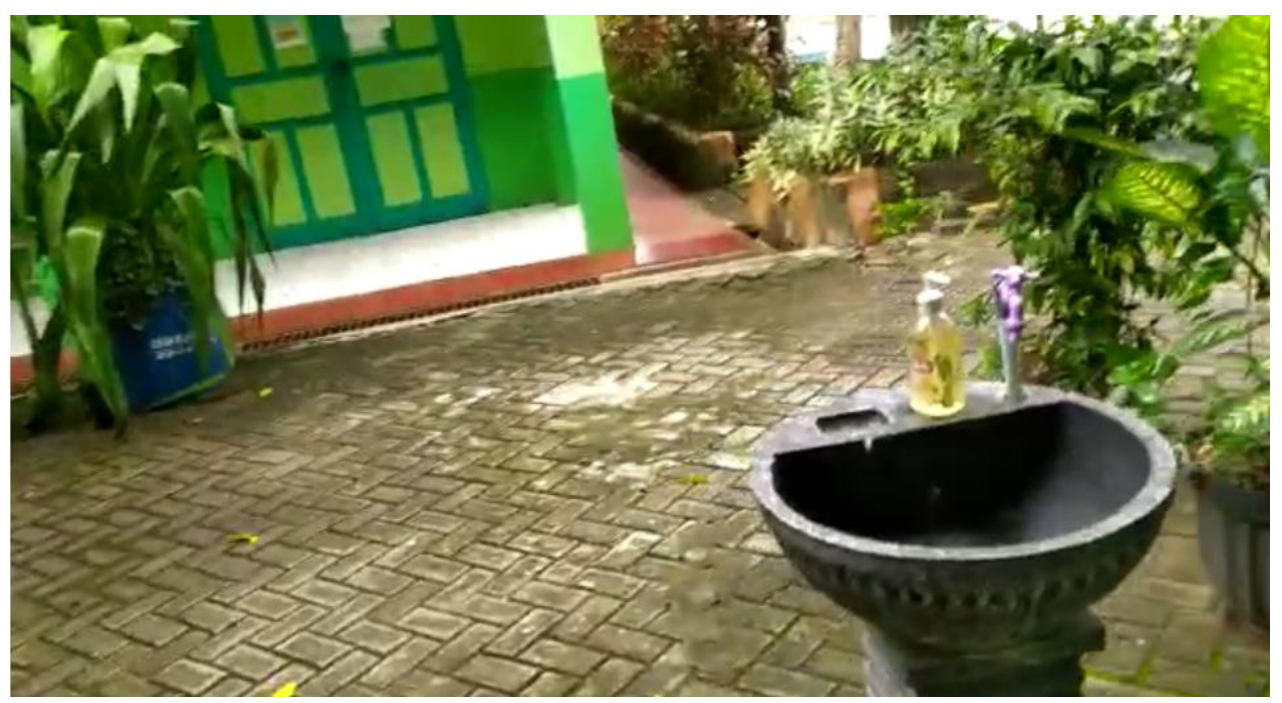

Gambar 3. Wastafel di halaman Sekolah

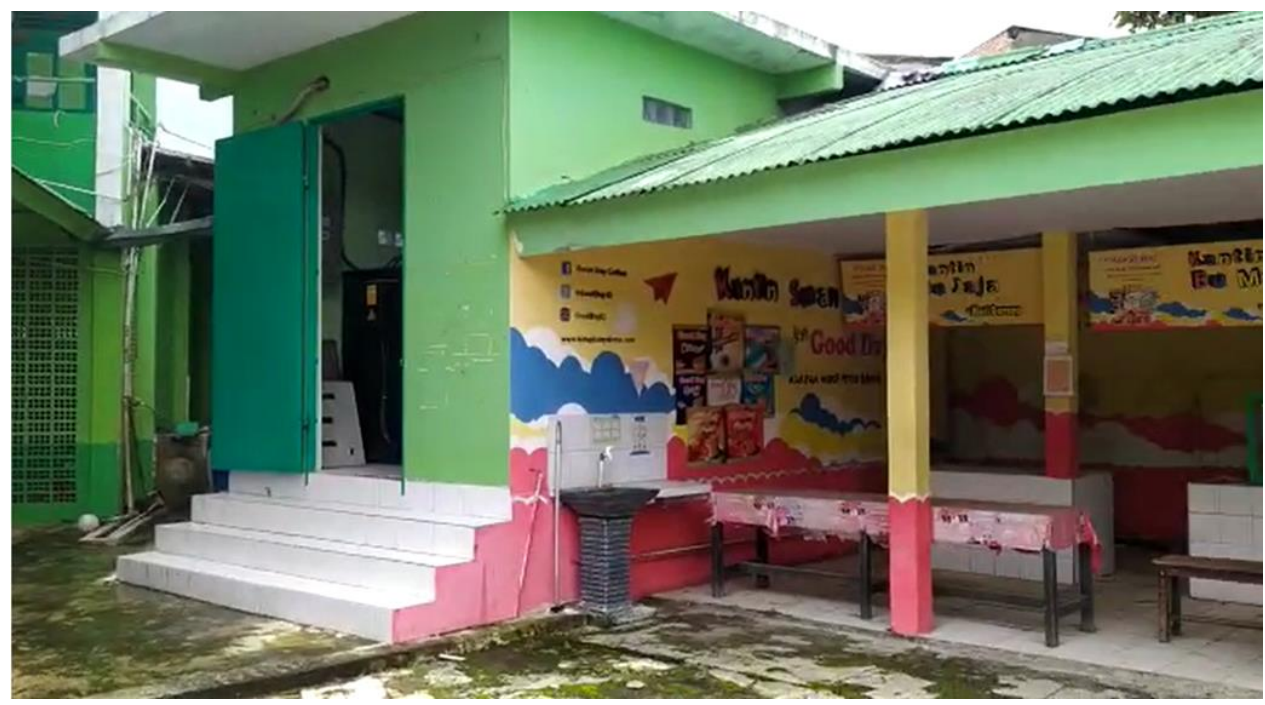

Gambar 4. Wastafel di kantin sekolah 


\section{METODE PELAKSANAAN PKM}

Tahapan/langkah-langkah solusi bidang edukasi di lingkungan sekolah

Tahapan atau langkah langkah tersebut sebagai berikut:

A. Survei lapangan, melihat situasi dan kondisi lingkungan sekolah secara umum dan khusus.

a. Secara umum adalah melihat prokes yang sudah tersedia atau dalam tahapan pelaksanaan tersedia yang ada dalam lingkungan sekolah atau ruang terbuka, antara lain:

i. Pekarangan sekolah termasuk parkir mobil, motor, dan sepeda

ii. Masjid atau mushola atau tempat ibadah lainnya

iii. Lapangan olah raga

iv. Kantin sekolah

v. Toilet

vi. Taman

vii. Tempat siswa istirahat saat ishoma

b. Secara khusus adalah melihat prokes yang sudah tersedia atau dalam tahapan pelaksanaan tersedia di luar wilayah 1a atau ruang tertutup atau tempat siswa interaksi dengan guru, antara lain:

i. Ruang kelas

ii. Laboratorium atau bengkel

iii. Ruang administrasi

iv. Ruang guru

v. Ruang kepala sekolah

vi. Dan lainnya dari yang belum disebut (i-v)

c. Mendata dan membuat rekaman lewat foto atau video dengan hp

B. Membuat persiapan untuk buku saku berdasarkan hasil survei dengan menyesuaikan teori dan lapangan yang ada

C. Berdasarkan rancangan atau draft buku saku, mulai dibuat bahan presentasi

D. Memperbanyak buku saku, merapihkan presentasi

E. Ke lapangan untuk membagikan buku saku dan presentasi di hadapan siswa siswi SMAN 96

Tahapan/langkah-langkah solusi bidang edukasi di luar lingkungan sekolah

Tahapan atau langkah langkah tersebut sebagai berikut:

A. Membuat persiapan untuk buku saku:

a. persiapan sekolah saat masih di rumah

b. selesai sekolah saat tiba di rumah

B. Berdasarkan buku saku no. A, mulai dibuat bahan presentasi untuk:

a. persiapan sekolah saat masih di rumah

b. selesai sekolah saat tiba di rumah

C. Memperbanyak buku saku, merapihkan presentasi

D. Ke lapangan untuk membagikan buku saku dan presentasi di hadapan siswa siswi SMAN 96

\section{HASIL DAN PEMBAHASAN}

Situasi dan kondisi saat survei pada tanggal 25 Februari 2021, dalam keadaan pembelajaran secara online. Keadaan sekolah sepi dari siswa siswi pelajar SMAN 96. Pagi hari tanggal 25 Februari 2021, berlangsung rapat koordinasi antara kepala sekolah dengan guru guru SMAN 96. Dengan ijin yang diberikan kepala sekolah Bapak Adil Minita Ginting, pengambilan foto dapat 


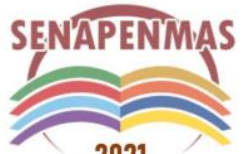

2021
Seminar Nasional Hasil Penelitian dan Pengabdian Kepada Masyarakat 2021 Pengembangan Ekonomi Bangsa Melalui Inovasi Digital Hasil Penelitian dan Pengabdian Kepada Masyarakat Jakarta, 21 Oktober 2021

dilakukan pagi hari tersebut dengan dibantu ibu Pardosi bagian administrasi sekolah. Berikut foto foto yang telah diambil pada pagi hari 25 Februari 2021 dapat di lihat pada Gambar 1 sampai dengan Gambar 4 di Pendahuluan Dari hasil survei, dilakukan pembahasan dengan membuat draft buku saku berdasarkan protokol kesehatan untuk warga satuan pendidikan yang terdiri dari pendidik, tenaga kependidikan, dan peserta didik, termasuk pengantar/penjemput (Kemdikbud, 2020). Hasil dari pembahasan diperoleh buku saku sebagai berikut:

A. Edukasi persiapan sekolah (saat masih di rumah)

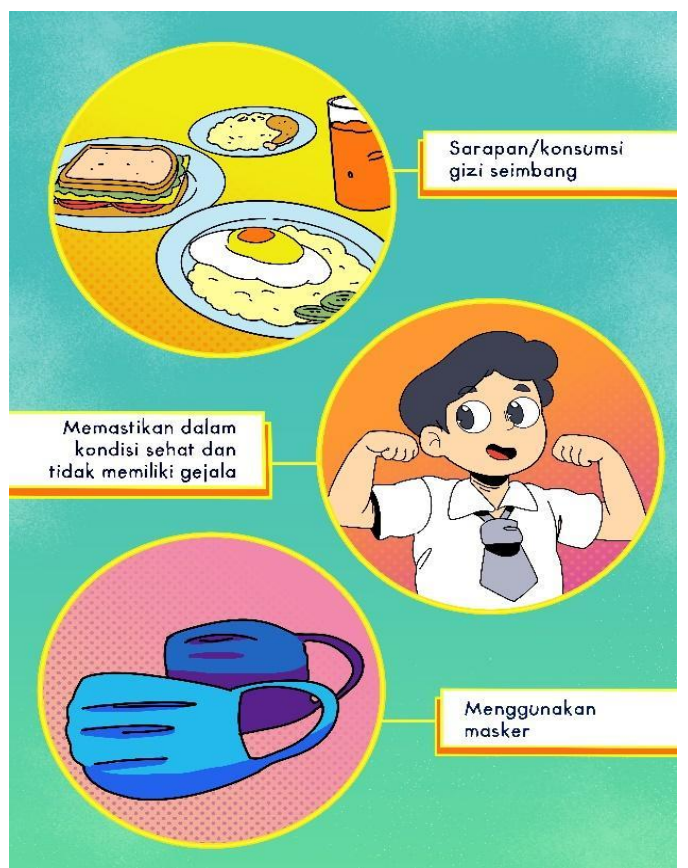

Gambar 5. Persiapan diri

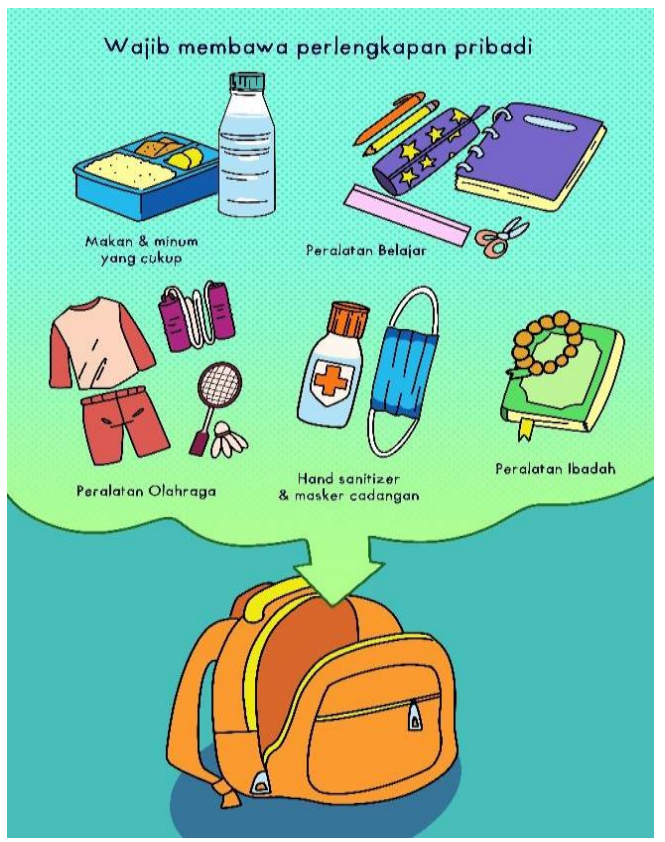

Gambar 6. Perlengkapan Pribadi 
B. Edukasi dilanjutkan dengan saat siswa melangkah masuk pekarangan sekolah, menunggu bel berbunyi, kemudian melangkah masuk ke ruang kelas.

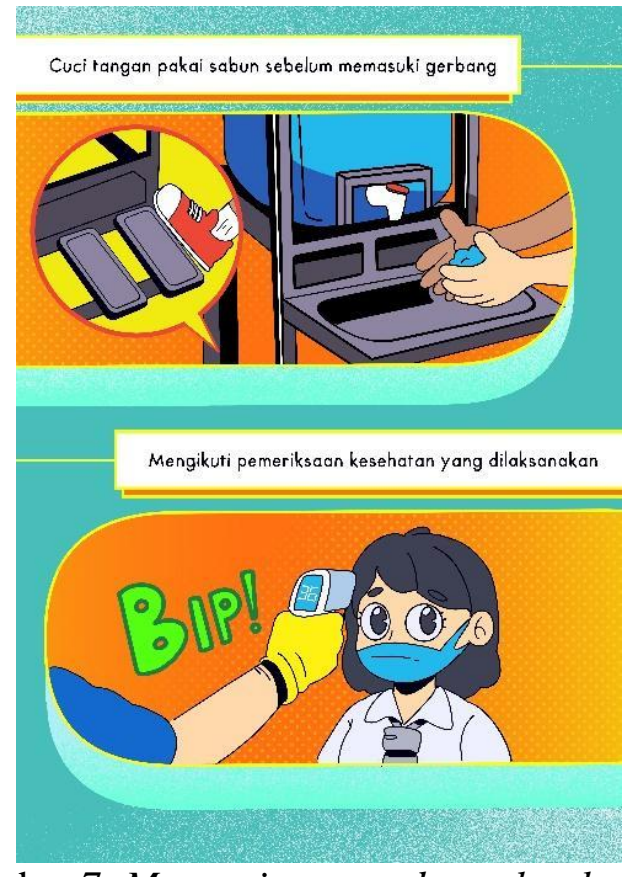

Gambar 7. Mencuci tangan dan cek suhu

C. Edukasi selama kegiatan belajar

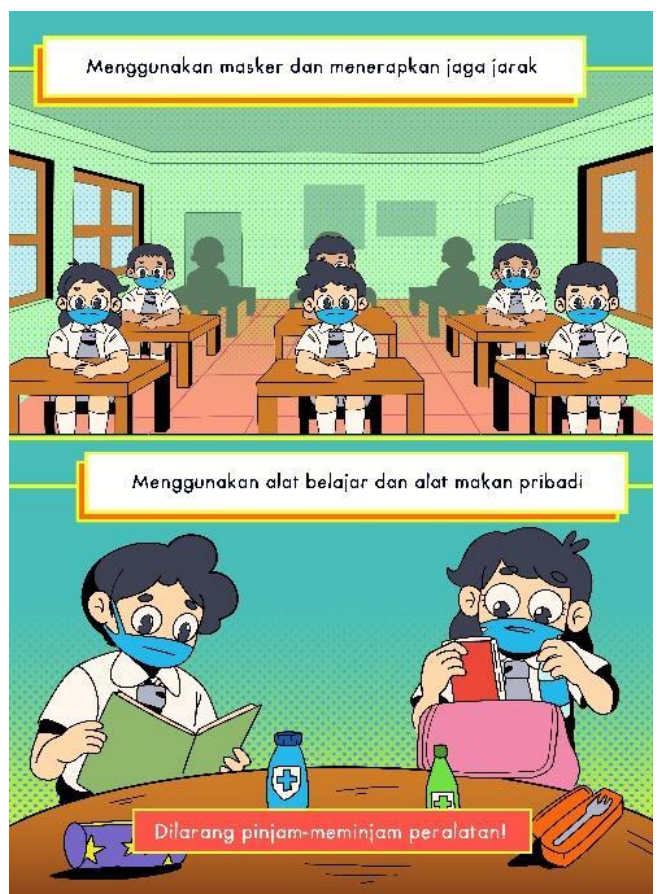

Gambar 8. Memakai masker dan peralatan pribadi

D. Edukasi saat pembelajaran selesai dan keluar ruang kelas lalu pulang 


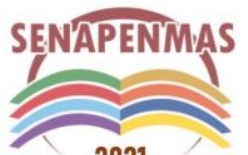

2021
Seminar Nasional Hasil Penelitian dan Pengabdian Kepada Masyarakat 2021

Pengembangan Ekonomi Bangsa Melalui Inovasi Digital Hasil Penelitian dan Pengabdian Kepada Masyarakat Jakarta, 21 Oktober 2021

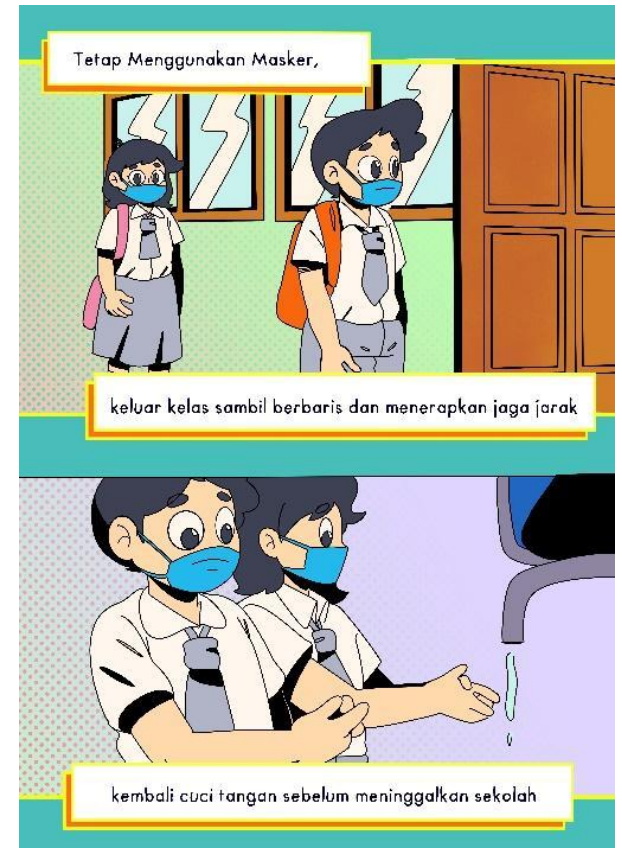

Gambar 9. Jaga jarak dan mencuci tangan

E. Edukasi saat sampai di rumah dan mulai berkegiatan di rumah

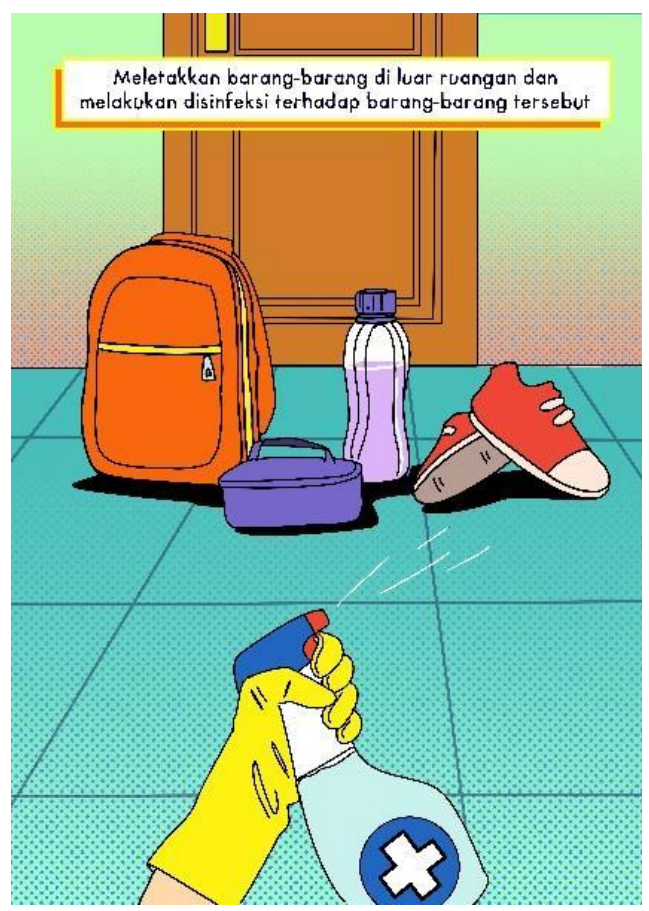

Gambar 10. Disinfektan terhadap barang-barang yang dipakai 


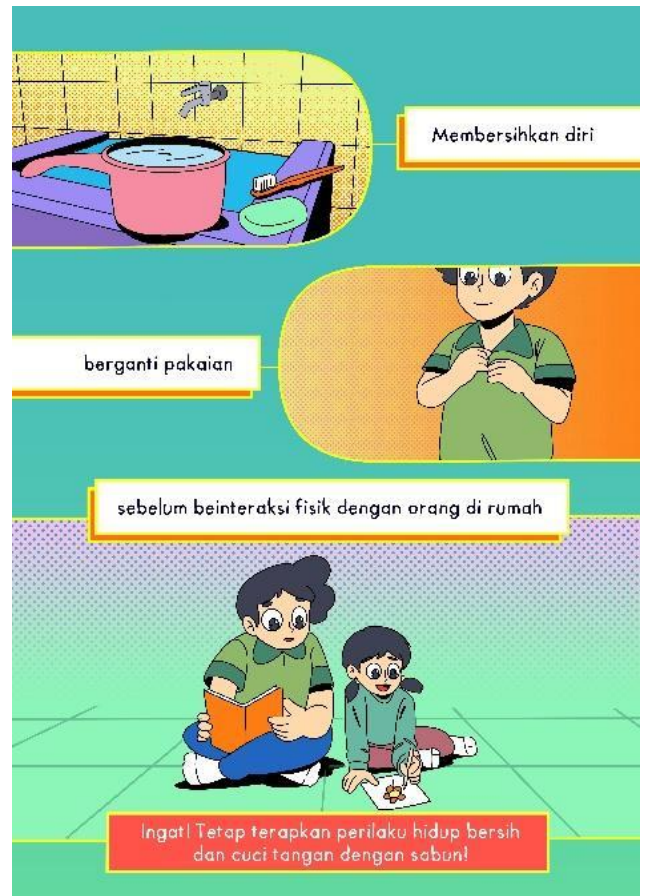

Gambar 11. Mandi, keramas, dan berganti baju

Karena situasi masih pandemi, maka buku saku dan bahan presentasi disampaikan ke pihak SMAN 96 Jakarta Barat.

\section{KESIMPULAN DAN SARAN}

Pihak SMAN 96 selain menyiapkan prokes di lingkungan sekolah, juga harus menyediakan waktu untuk selalu mengingatkan prokes dan berperilaku hidup sehat di sekolah dengan membagikan buku saku dan memberikan edukasi lewat presentasi. Buku saku selain hardcopy juga ada softcopy

\section{Saran yang dapat diberikan sebagai berikut:}

a. Dari hasil survei dapat disimpulkan titik titik atau spot tempat untuk melakukan periksa suhu dan tempat mencuci tangan pada lokasi gerbang sekolah sesuai Gambar 1.

b. Harus disiapkan garis garis berjarak 1,5 meter pada gerbang sekolah dan setiap pintu ruang kelas untuk antrian masuk dan jaga jarak. Begitu juga saat pulang sekolah.

c. Wastafel untuk cuci tangan diperbanyak pada lokasi kantin.

d. Penempatan hand sanitizer pada setiap pintu ruang kelas dan kantor

\section{Ucapan Terima Kasih}

Pengabdian Kapada Masyarakat ini didanai oleh LPPM Periode I tahun 2021 Universitas Tarumanagara. Tim PKM mengucapkan terima kasih kepada Penelitian dan Pengabdian Masyarakat Universitas Tarumanagara yang mendukung pembiayaan penelitian ini dan staf. Terima kasih juga disampaikan kepada Program Studi Sarjana Teknik Sipil. Semoga PKM ini dapat bermanfaat bagi SMAN 96 Jakarta.

\section{REFERENSI}

Joko, B. S., Kesiapan Sekolah Pasca akan diperbolehkan Pembelajaran Tatap Muka, Forum 
Komunkasi Pendidikan dan Kebudayaan15 Desember 2020, PUSAT PENELITIAN KEBIJAKAN PENDIDIKAN DAN KEBUDAYAAN KEMENTERIAN PENDIDIKAN DAN KEBUDAYAAN, 2020

Kemdikbud, 2020, Buku Saku Panduan Pembelajaran di Masa Pandemi Covid-19, 30 Juni 2020, https://www.kemdikbud.go.id/main/blog/2020/06/buku-saku-panduan-pembelajaran-dimasa-pandemi-covid19

KEPUTUSAN BERSAMA MENTERI PENDIDIKAN DAN KEBUDAYAAN, MENTERI AGAMA, MENTERI KESEHATAN, DAN MENTERI DALAM NEGERI REPUBLIK INDONESIA, NOMOR 01/KB/2O2O, NOMOR 516 TAHUN 2O2O, NOMOR HK.03.0 1 /Menkes / 363 / 2O2O, NOMOR 440-842 TAHUN 2020

KEPUTUSAN BERSAMA MENTERI PENDIDIKAN DAN KEBUDAYAAN, MENTERI AGAMA, MENTERI KESEHATAN, DAN MENTERI DALAM NEGERI REPUBLIK INDONESIA, NOMOR 03/KB/2020, NOMOR 612 TAHUN 2020, NOMOR HK.01.08/Menkes/502/2020, NOMOR 119/4536/SJ

KEPUTUSAN BERSAMA MENTERI PENDIDIKAN DAN KEBUDAYAAN, MENTERI AGAMA, MENTERI KESEHATAN, DAN MENTERI DALAM NEGERI REPUBLIK INDONESIA, NOMOR 03/KB/2O21, NOMOR 384 TAHUN 2O2O, NOMOR HK.01.08 /Menkes / 4242 / 2O2O, NOMOR 440-717 TAHUN 2021

KPAI, Survei KPAI: 76,7\% Siswa Tidak Senang Belajar dari Rumah, 27 April 2020, https://kumparan.com/kumparanmom/survei-kpai-76-7-siswa-tidak-senang-belajar-darirumah-1tJ084bBo3k/1

Nugroho, M.S., Syamsuar, A,Syamsuar, A, Yunaryo, H.M.A., Pramesti, L.A., Nurrudin, M., Darmamulia, M.A., Fasya, R.A., Haniffah, S.H., Gaol, S.I.P.L., Ernawati. (2020). Analisis Kesiapan Pelaksanaan Kegiatan Pembelajaran Tatap Muka di Indonesia pada Tahun 2020. Journal Publicuho. Vol 3 No 3, pp 523-542, DOI:10.35817/jpu.v3i4.15522

Sahara, Wahyuni. (2021, Agustus 25). Perjalanan Covid-19 di Indonesia hingga Mencapai 4 Juta Kasus. Diakses dari https://nasional.kompas.com/read/2021/08/25/05330031/perjalanancovid-19-di-indonesia-hingga-mencapai-4-juta-kasus.

Unicef, 2020, Indonesia: Survei terbaru menunjukkan bagaimana siswa belajar dari rumah, 16 Juni 2020, https://www.unicef.org/indonesia/id/press-releases/indonesia-survei-terbarumenunjukkan-bagaimana-siswa-belajar-dari-rumah 
Seminar Nasional Hasil Penelitian dan Pengabdian Kepada Masyarakat 2021

Pengembangan Ekonomi Bangsa Melalui Inovasi Digital Hasil Penelitian dan

Pengabdian Kepada Masyarakat

Jakarta, 21 Oktober 2021

(halaman kosong) 